\title{
MIR29B2 wt Allele
}

National Cancer Institute

\section{Source}

National Cancer Institute. MIR29B2 wt Allele. NCI Thesaurus. Code C81915.

The human MIR29B2 wild-type allele is located in the vicinity of $1 \mathrm{q} 32.2$ and is 80 bases in length. This allele, which encodes MIR29B2 RNA, plays a role in lung cancer,

cholangiocarcinoma, rhabdomyosarcoma, chronic lymphocytic leukemia, acute myeloid leukemia, Alzheimer's disease and type 2 diabetes. 